\title{
ENTREPRENEURIAL FUNCTIONALITY OF NEW VENTURE CREATION LEARNERS
}

\author{
PHILNA BUYS \\ Philna@mtnloaded.co.za \\ KLAAS HAVENGA \\ onbjjdh@puk.ac.za \\ Department of Human Resources Management \\ University of Johannesburg
}

\begin{abstract}
The primary objective of this study was to evaluate the suitability of individuals as potential entrepreneurs in the entrepreneurial economic environment. The scientifically validated Functional Intelligence Assessment Tool (FIAT) was applied to nineteen individuals (learners) during their training (New Venture Creation Learnership or NVC Learnership) which was managed by the Services Sector Education and Training Authority (SETA). Only three of the nineteen respondents were found to be suitable as entrepreneurs of whom two also displayed leadership qualities. The implications of the findings are discussed.
\end{abstract}

Key words

Entrepreneurs, perception, new venture, functional intelligence, learnership

Small business is said to drive the economy of a country. In terms of the South African environment, Schwenke and Van Heerden (2002) are confident that entrepreneurship is "...the way of the future and that job growth can and will only come from SMEs (small and medium enterprises)". Schwenke et al., further concludes that as a tool of job creation, enablement and entrepreneurial development, SMEs are at the "...vanguard of change in the local economy" (Schwenke et al). It is therefore critical that the entrepreneurs in a country are identified early and skilled appropriately (through learnerships or other educational routes). It is equally important that individuals that are not entrepreneurs be found their rightful vocation and then everyone can contribute effectively to the economic activity.

The skills shortage is one of the problems that exists in South Africa as a result of its historic political situation. According to the Department of Labour (2001a), the composition of the workforce during 1970-1995 was dominated by Caucasion males while Africans (blacks) were employed in the unskilled occupations. This situation has indeed remained unchanged as seen when a comparison was made between Europeans (whites) and Non-Europeans (Blacks, Indians, Coloureds) for the period 1904 to 1931 [R.J. Van Reenen, M. Visser, E.H.D. Arndt, H.F. Champion, D.M. Davidson, A.J. Downes, W. Freestone, 1935, p. 12].

This was due partially to the fact that whites tried to minimize any 'threat' from any source (Botha, Calder, Fichardt, Bosman, Slabbert, Smuts, Van den Berg and Windsor, 1951, p. 163). Their particular concern was equal opportunities to acquire skills which lessened their chances of being gainfully employed. The educational backlog originated as far back as 1950 when South Africa was still a Union governed by the British Monarch from 1910 to 1948 and the education system was segregated along racial lines through the Population Registration Act of 1950 (Du Pre, 2004). Job reservation for black people was limited to certain forms of labour which at most was semi-skilled (Fryer, 2003). Acquiring skills was therefore reserved mainly for whites until the elections in 1994 which brought a change in leadership and a democratic government, which had as its primary mission, skills development for all. On a macro level, South Africa was marginalized from global participation and on a micro level, many people were not able to even enter the workforce because of a lack of skills, let alone be active in the economy.

The South African government's resultant Human Resources Development (HRD) and National Skills Development Strategy
(NSDS) were driven by supportive legislation, namely the Skills Development Act No 97 of 1998, Employment Equity Act No 55 of 1998, Skills Development Levies Act of 1999 and the South African Qualifications Authority Act No 58 of 1995 (Department of Labour, 2001a, b).

These strategies and legislative measures intended to address the skills shortages and directly stimulate entrepreneurial potential through the implementation of learnerships as a national qualification. The term 'learnership' or 'learnerships' is a comprehensive description that groups together all the learnerships that are registered with the South African Qualifications Authority (SAQA). One of the core components of an entrepreneurial culture is education, and how various educational programmes can incorporate entrepreneurship is a subject area which will foster enterprising or new venture creation (Hynes, 1996. pp. 10 - 17).

Learnerships were preceded by the apprenticeship system intended for blue collar workers operating mainly in the trade/manufacturing sector. The promulgation of the first legislation regarding apprenticeships was the Apprenticeship Act of 1922 as part of an attempt by the South African government to regulate its labour situation (Van Reenen, et al, 1935, p. 11).

Following on from the high level HRD strategy were the initial over-ambitious targets for people to become qualified learners. The result was a push-through effect of individuals who were not necessarily suited to a particular learnership or able to function at the required standard (National Qualifications Framework or NQF Level 4 that is equal to grade 12). Low level evaluations were used to 'certify' potential learners in terms of their numeracy and literacy levels only. The absence of a suitable assessment has been recorded in the Report of the Industrial Legislation Commission of 1935 which commented on the fact that individuals were employed on face value or because of business relations with the individual's father (Van Reenen, et al, 1935).

\section{PURPOSE AND OBJECTIVE}

This situation described above provided an opportunity to evaluate the suitability of learners on the New Venture Creation Learnership in terms of their entrepreneurial functionality and leadership qualities, to establish if they would be suited to function in the entrepreneurial environment. 
While psychological analysis can test various skills/proficiencies, it can never test the functionality of the congruent, holistic man within a specific environment. The core criterion in measuring any human functioning is environment. By excluding the environment in any quantification or measurement of human functioning, the information becomes non-effective (Whitehouse, 2002).

It was also necessary to identify the functionality of all individuals who intended to be trained via any learnership before they were 'evaluated' by the SETA in terms of their numeracy and literacy levels (only). The value of applying a scientific evaluation model to assess respondents for suitability extends beyond learnerships. It can also be applied in the workplace for people who are already employed. Productivity and workforce impact can both be improved substantially if people can operate in an environment to which they are best suited. The government, SETAs and employers in general can allocate funds more appropriately to allow more people the opportunity to become skilled, albeit through other education routes or training providers.

Through various aspects essential to the entrepreneur's environment, growth and development, it became apparent that the entrepreneur needs a more protected environment than what might currently be in place, despite efforts from the South African government to improve the situation. It supports the developing trend in the number of entrepreneurship education and training initiatives which support the idea that entrepreneurs can be made and thus the perception that entrepreneurship can be taught (Faris, 1999).

A partnership (temporary/permanent) of a potential entrepreneur and an existing successful business with the intention of 'cloning' some or all aspects of an entire business and constructing eventual reciprocate relationships, is suggested (refer Figure 1). Such partnerships represent the empowerment of the entrepreneur and it is within the context of the Partnership Entrepreneur, that an entrepreneur is considered an inspired individual who excels at creating employment (of self and others) by making use of an existing successful partnership to create a separate entity. Yet, the individual must still be able to function as an entrepreneur (generate ideas, take risk, create employment) otherwise the support and guidance in the form of the partnership is of little use. Entrepreneurship education is also found to contribute significantly to risk-taking, the creation of new ventures and the tendency to self-employment (Charney \& Libecap, 2002). The skills, productive citizenship and employment status concerning the entrepreneur is contained in the vision of the NSDS.

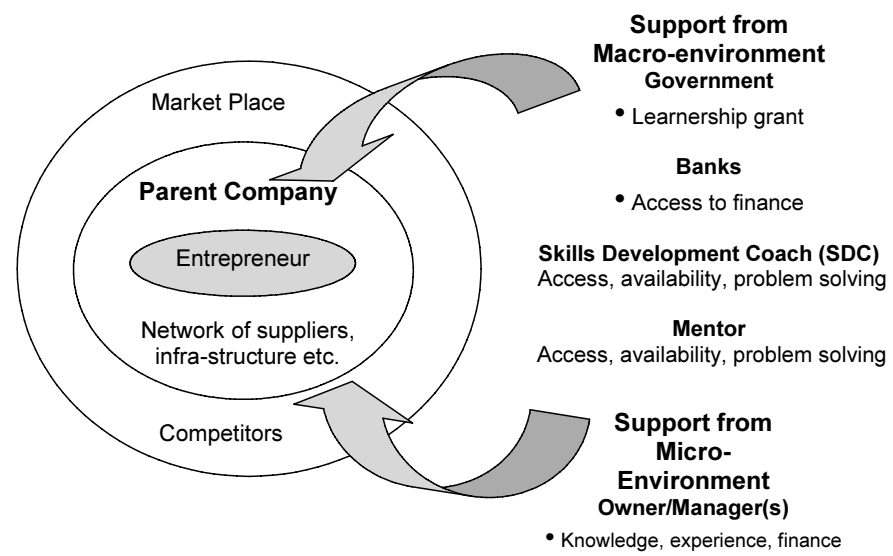

Figure 1: Partnership Entrepreneur Environment Source: Anonymous, 1995m; Anonymous, 2004p; Anonymous, 1999q Hernandez-Gantes-Nieri (n.d.) and Lumpkin and Dess (1996, p. 36 as quoted by Caree and Thurik (2002, p. 4))

\section{RESEARCH DESIGN}

The nature of this study required a multi-pronged approach to collecting the data. The first step was an examination of the (numeracy and literacy) evaluation methods applied by the SETA prior to the commencement of the training of these individuals. The analyses of the results of these individuals (learners) during their training were the second step, while using the Functional Intelligence Assessment Tool (FIAT) was the third step.

\section{Research Approach}

Figure 1 sets out the research approach that resulted in three sets of data. The first data set consisted of two phases: Phase I was an interview conducted by interviewers appointed by the SETA and Phase II the "Star In-Basket" exercise that determined the candidate's ability to handle various situations depicted as items in a person's in-basket. The latter phase required the individual to complete a number of paper-based exercises that were marked manually by the SETA. It assessed the learners' ability in Communication in English (Written), Mathematical Literacy, Recognise Effect of HIV/AIDS in the Workplace, Customer Service, Planning and Time Management, Working in a Team and Simple Problem Solving and was considered to be core learning. Separate numeracy placement assessment and communication assessment tools completed the preassessment measurement (Phase II). The second set was the learners' results during their learnership training and were obtained from the accredited training provider that reports to the SETA. The third set was the individual analyses of the computer-based Functional Intelligence Assessment Tool (FIAT) that consisted of two questionnaires, 300 questions each - one for suitability as an entrepreneur and the other for leadership qualities.

The Personal Values of the respondent were firstly ranked in order of importance and then matched against those of the organization (Corporate Values) as set by existing entrepreneurs prior to commencing the research process. The same process was applied for the leadership qualities.

The nature of the Functional Intelligence Assessment Tool (FIAT) necessitated a detailed analysis of each individual's assessment because of the grouping of the constructs detailed above.

\section{Research methodology}

Participants/Respondents

Participants were sampled using the purposive or judgmental sampling method intended for special situations (such as a small sample and the intensity of the assessments (Neuman, 2003, p. 213). They were all learners who were in the process of completing the New Venture Creation Learnership at an events management company in Johannesburg, South Africa. A telephonic interview with the manager who worked closely with the respondents in the company assisted in selecting twenty respondents for this study.

\section{Biographical Data}

The twenty respondents were all black Africans and comprised eleven females (seven under the age of 30, three between 30 and 40 years and one of 44 ) and nine males (eight males under the age of 30 years and one male of 39 years of age).

\section{Measuring Instruments}

A great deal of research on personality characteristics and sociocultural backgrounds of successful entrepreneurs was conducted in the past three decades. In general, characteristics most often contributed to entrepreneurs are: commitment and determination, leadership, opportunity observation, tolerance of risk, ambiguity and uncertainty, creativity, self-reliance and ability to adapt and motivation to excel. (Byers, Kist and Sutton, 1997). Major models used to predict the three most important 
entrepreneurial success factors (need for achievement, need for power, risk taking propensity and competitive situation) are the Didato Achievement Motivation Scale (A.J. Dubrin, R.D. Ireland, and J.C. Williams, 1989); the Scale for need for power (K. Hashemi, and M. Shirazi, 1994) and Miner's competitive situation sub-scale (J.B. Miner, 1994, pp. 62-68).

The following models (Carland Entrepreneurial Index, the Baron Emotional Intelligence test and the Myers-Briggs Type Indicator) were considered before the Functional Intelligence Assessment Tool (FIAT) scientific model was selected because of its holistic approach to the individual and his/her functionality within an environment:

- The Carland Entrepreneurial Index drew on the research "...of leading researchers in entrepreneurial planning, characteristics, behavior and distinctions, and borrowing heavily from the literature of cognitive psychology, the authors have developed a short, objective instrument which will yield an index of entrepreneurship". This index is an indication of the strength of the "...relative entrepreneurial preferences of respondents." (J.W. Carland, J.C. Carland, and H. Frank, 1992). The Carland Entrepreneurial Index focuses on four elements cited from literature: personality, innovation, risk taking propensity, and strategic posture and the authors "...devised statements in pairs in a forced choice format which would reveal an individual's proclivity for each of those four constructs" (Carland et al. (1992)).

- Bar-on Emotional Intelligence test or Bar-On EQ-i inventory "...describes a cross-section of interrelated emotional and social competencies, skills and facilitators that impact intelligent behavior, measured by self-report (Bar-On 1997a, 1997b) within a potentially expandable multi-modal approach including an interview and multirater assessment (Bar-On \& Handley, 2003a, 2003b). Emotional-social intelligence has one or more of the following key components: “...(a) the ability to recognize, understand and express emotions and feelings; (b) the ability to understand how others feel and relate with them; (c) the ability to manage and control emotions; (d) the ability to manage change, adapt and solve problems of a personal and interpersonal nature; and (e) the ability to generate positive affect and be self-motivated." (Bar-On et al. 2003a, 2003b).

- Myers-Briggs Type Indicator - Carl G. Jung introduced the theory of psychological type in the 1920s and this was further developed in the 1940s by Isabel Briggs Myers with ongoing research. Its popularity is evident in the fact that more than two million people worldwide take the Indicator each year (Anonymous, (n.d.)b).

The MBTI identifies and describes 16 distinctive personality types that result from the interactions among the preferences of people. It uses guidelines such as one's 'Favorite World', (whether you prefer to focus on the outer world or on your own inner world). This is referred to as Extraversion (E) or Introversion (I); Information (do you prefer to focus on the basic information you take in or do you prefer to interpret and add meaning?). This is called Sensing (S) or Intuition (N); Decisions (do you prefer to first look at logic and consistency or first look at the people and special circumstances?). This is called Thinking (T) or Feeling (F); Structure (in dealing with the outside world, do you prefer to get things decided or do you prefer to stay open to new information and options?). This is called Judging ( $\mathrm{J}$ ) or Perceiving (P) (Anonymous, (n.d.)b.).

If one knows ones MBTI type it will help a person to decide what specific areas of law, medicine, education, or business you prefer. "A person with a preference for Introversion may find he or she is happier doing research, while a person who prefers Extraversion may favor a field with more interaction with people." (Anonymous, (n.d.)b.). The MBTI is perhaps the closest aligned to the work environment and its influence on how comfortable you are at your job, and can "...help you discover and use your strengths to accomplish the work. When you find an unsatisfactory job fit, you can examine the reasons and seek solutions based on your preferences. "(Anonymous, (n.d.)b.).

Research in the fields of ecology and ecometrics was originated in 1960 by its founder member Van Zyl (Whitehouse, 2002). In its 45 year history a number of other leaders in this field contributed greatly to the development thereof (Whitehouse 2002). They are Faul, Horne, Hudson and many others [B.I. Horne, (1999); W.W. Hudson, A.C. Faul, and B. Hanekom, (2000)]. Functional Intelligence is the occupation in which ecometrics is used to quantify the criteria of human behaviour in a given environment (Whitehouse, 2002). The Functional Intelligence Assessment Tool (FIAT) therefore identified and substantiated the suitability or non-suitability of the respondents in terms of entrepreneurial requirements. FIAT is unique in the sense that it scientifically measures the influence of the environment on the individual and the individual's response to that environment (Whitehouse). An additional questionnaire was administered to evaluate leadership qualities which are an essential component of the entrepreneur.

Guiding one's decisions and behaviour are one's perceptions and in its purest form, the word 'perception' is defined as "...the process, act, or faculty of perceiving" (Anonymous, (n.d.) a) and our perceptions influence our Internal Interaction System (IIS) and our General Behavioral System (GBS). The General Behavioral System (GBS) gives sight of peoples' feelings and emotions. In other words it is how the candidate portrays him/herself - what one can see. This system is used when talking, interviewing or watching the candidate's behaviour. Through comparisons, one can determine if the candidate is an extrovert or an introvert. The IIS and GBS are independent of each other and affect a person's functioning independently. The significant difference between the IIS and GBS systems is that most people seem to understand the GBS because it is the biggest diversion from the reality of truth (Whitehouse, 2002).

Perception is therefore a critical element based on the six (separate) superconstructs (areas) used in the FIAT which are the ones that people function from, each with their related constructs:

1. Positive Functioning Areas: These indicate one's Inner Interactive System (Self- Perception), or IIS:

- Achievement (IIS and GBS) is accomplishment, success, realization.

- Satisfaction (IIS and GBS) is contentment, fulfillment and approval.

- Expectations (IIS and GBS) are the outlook (positive orientation), potential, hope and opportunity of the individual towards his/her future involving emotional experience and cognitive appraisal of one's life from an optimistic point of view.

2. Negative Functioning Areas: Indicates General Behaviour System (Self- Portrayal System) or GBS:

- Frustration (IIS and GBS) is aggravation, irritation, disturbance, annoyance, disappointment, dissatisfaction.

- Stress (IIS and GBS) is pressure, strain, anxiety, tension.

- Helplessness (IIS and GBS) is defenselessness, exposure, vulnerability.

3. Self-Perception Areas:

- Inner Insecurity - state of not being secure; experiencing fear or anxiety.

- Guilt Feelings - conscious of guilt; state of having done wrong.

- Lack of Self Worth - lack of quality which renders a thing valuable; perception of the individual that 
he/she is unimportant and does not mean anything to others; is not special and does not deserve to be handled with respect.

4. Relationship Areas:

- Colleagues

- Partner

- General

5. Emotional Functioning Areas:

- Dependency (addiction, reliance)

- Disturbing Thoughts

- Memory Loss

- Paranoia (fear, suspicion, mistrust, people talking behind your back)

- Anxiety (nervousness, concern, apprehension)

- $\quad$ Senselessness of Existence.

6. Corporate Functioning areas:

- Job Satisfaction

- Job Security

- Equality

- Effectiveness of Supervisor

- Supervisor's Leadership Ability (Staff Perception)

- Supervisor's Communication Skills (Staff Perception)

- Supervisor's Communication Skills.

\section{RESULTS}

The data of the respondents for Phase I (pre-assessment interview) were available in hard copy and were obtained with permission from the Services SETA (SS) while the data for Phase II (core learning) were obtained from the accredited training provider electronically.

The Services Seta (SS) Criteria are linked to the objectives of the overall HRD Strategy. Objective 1 of the HRD required the beneficiaries of learnerships to be $85 \%$ black, $54 \%$ women and $4 \%$ disabled to fulfill the equity target. Objective 6.1 of the HRD required that a minimum of 80000 people under the age of 30 would have entered learnerships by March 2005 to fulfill the assistance of employees under the age of 30 into employment. Points were allocated according to these objectives listed below (refer Table 1):

I. Race: Black/Asian/Colored -3 points; white -1 point.

II. Gender: Female -2 points; male -1 point.

III.Age: Over $35-1$ point; under $35-3$ points.

IV. Disability: Disability - 2 points; no disability -1 point.

V. Education: Meets educational pre-requirements -3 points; does not meet educational pre-requirements -1 point.

The questionnaire points refer to the pre-assessment interview for which points were also allocated. The comments of the candidate were noted after each question and the case worker could also tick his/her opinion if the candidate answered coherently (2 points), answered satisfactorily, but not coherently (1 point) or could not answer (0 points). The questions used were:

Question 1: What job do you think someone who qualifies in this learnership will be able to do, and describe your daily activities, as you understand them.

Question 2: Why do you want to do this learnership?

Question 3: Do you have facilities to study in at home and will you be able to devote yourself to your studies this year? Do you have adequate time to dedicate to your studies while working full time?

Question 4: How long have you been in this industry and why do you want pursue a career in (learnership category)?

Question 5: Why should you be selected for this learnership over everyone else?

Question 6: If you are successful, how will you ensure that you complete the learnership and do not drop out - thereby taking the opportunity from someone else who could have been selected?

The 'General Observations' elements rated general spoken communication skills, written communication skills (apart from the separate literacy assessment), self-presentation, enthusiasm for the opportunity, impact, timekeeping, realism about the process and general business knowledge. The case worker could allocate 2 points (excellent) or 1 point (good) or 0 points (poor) for these elements.

TABLE 1

Pre-assessment interview results - PhaSe 1

\begin{tabular}{|c|c|c|c|c|}
\hline Respondent & $\begin{array}{l}\text { SS Criteria } \\
\text { (Max 13 } \\
\text { Points) }\end{array}$ & $\begin{array}{l}\text { Question- } \\
\text { naire points } \\
\text { (Max } 28 \\
\text { Points) }\end{array}$ & $\begin{array}{c}\text { Total Points } \\
\text { (Max } 41 \\
\text { Points) }\end{array}$ & $\begin{array}{c}\text { General } \\
\text { Observations } \\
\text { (Incl in } \\
\text { Quest Points) }\end{array}$ \\
\hline 1 & 12 & 25 & 37 & 13 \\
\hline 2 & 11 & 21 & 32 & 9 \\
\hline 3 & 9 & 26 & 35 & 14 \\
\hline 4 & 11 & 20 & 31 & 10 \\
\hline 5 & 11 & 22 & 33 & 11 \\
\hline 6 & 11 & 20 & 31 & 10 \\
\hline 7 & 12 & 27 & 39 & 11 \\
\hline 8 & 12 & 25 & 37 & 13 \\
\hline 9 & 12 & 26 & 38 & 14 \\
\hline 10 & 12 & 25 & 37 & 13 \\
\hline 11 & 12 & 21 & 33 & 9 \\
\hline 12 & 12 & 25 & 37 & 13 \\
\hline 13 & 11 & 22 & 33 & 10 \\
\hline 14 & 11 & 26 & 37 & 14 \\
\hline 15 & 10 & 18 & 28 & 6 \\
\hline 16 & 11 & 25 & 36 & 13 \\
\hline 17 & 12 & 26 & 38 & 16 \\
\hline 18 & 12 & 26 & 38 & 14 \\
\hline \multicolumn{5}{|l|}{$19^{*}$} \\
\hline 20 ** & 12 & 21 & 33 & 9 \\
\hline Total & 216 & 447 & 663 & 222 \\
\hline Average*** & 11 & 24 & 35 & 12 \\
\hline
\end{tabular}

* No SETA detail available

** Did not complete the functional assessment

*** Average calculated for data of 19 respondents

Phase II, named the Star In-Basket, These items required the candidate to write instructions to his/her staff when he had just returned from holiday and was destined for a sales conference the next week. Various internal memorandums, notes from staff, internal e-mail and formal letters from clients make up the inbasket (refer Table 2).

This exercise assessed the candidate's ability in terms of the following items considered to be core learning: Communication in English - Written (candidate had to respond in writing on the document), Mathematical literacy (candidate had to, for example, calculate Value Added Tax V.A.T at $14 \%$ as well as the total amount for an invoice), Recognize the effect of HIV/AIDS in the workplace (candidate had to respond to a staff member who feels discriminated against because of his HIV status), Customer service (candidate had to respond to a customer complaining about the company's products and after-sales service), Planning and Time Management (candidate had to respond to a plan of his/her diary after the sales conference in view of important business lunches, meetings and prioritizing his/her work), Working in a team (candidate had to respond to the finance department experiencing frustration with the other departments) and Simple Problem Solving (candidate had to respond to a staff member who was not at work because of personal reasons). 
TABLE 2

Pre-assessment Results - Phase II

\begin{tabular}{|c|c|}
\hline Respondent & Score \\
\hline 1 & 17 \\
\hline 2 & 20 \\
\hline 3 & 24 \\
\hline 4 & 22 \\
\hline 5 & 21 \\
\hline 6 & 18 \\
\hline 7 & 15 \\
\hline 8 & 17 \\
\hline 9 & 15 \\
\hline 10 & 19 \\
\hline 11 & 23 \\
\hline 12 & 18 \\
\hline 13 & 12 \\
\hline 14 & 25 \\
\hline 15 & 13 \\
\hline 16 & 18 \\
\hline 17 & 25 \\
\hline 18 & 26 \\
\hline \multicolumn{2}{|l|}{19} \\
\hline 20 & 14 \\
\hline Total * Respondent 19 excluded & 362 \\
\hline
\end{tabular}

Of these items, Communication, Mathematics, Teamwork and Problem Solving have been identified in the pre-assessment, the learnership results and some in the FIAT. Table 3 gives a summary of the scores for all the above categories obtained by the candidates.

TABLE 3

SUMMARY CORE LEARNING - COMPETENT/NOT COMPETENT

\begin{tabular}{|c|c|c|c|c|c|c|}
\hline \multirow[t]{2}{*}{ Core learning assessed } & \multicolumn{6}{|c|}{ Candidates } \\
\hline & Competent & $\begin{array}{c}\text { Not } \\
\text { Competent }\end{array}$ & Comp. & $\begin{array}{l}\text { Not } \\
\text { Comp. }\end{array}$ & Total & $\%$ \\
\hline $\begin{array}{l}\text { Communication } \\
\text { in English: Written }\end{array}$ & All & & & 19 & 19 & $100 \%$ \\
\hline Mathematical Literacy & & $7,8,9,13,14$ & 5 & & 5 & $26 \%$ \\
\hline $\begin{array}{l}\text { Recognise effect of HIV/ } \\
\text { AIDS in the Workplace }\end{array}$ & 13 & & 1 & & 1 & $5 \%$ \\
\hline Customer Service & All & & & 19 & 19 & $100 \%$ \\
\hline $\begin{array}{l}\text { Planning \& time } \\
\text { management }\end{array}$ & & $5,7,12$ & 3 & & 3 & $16 \%$ \\
\hline Working in a team & & 20 & 1 & & 1 & $5 \%$ \\
\hline Simple problem solving & & $\begin{array}{c}1,2,6,7,9,10 \\
12,13,15,16,20\end{array}$ & 11 & & 11 & $58 \%$ \\
\hline
\end{tabular}

The reports for the learnership results (extract of one respondent's results shown in Table 4) were obtained from the training provider during the training and were reported in three categories - Achieved (assessed within the workplace or work required for the learner's portfolio of evidence (POE)), Summative (a project or assignment) and Formative (presentation in class) listed in Table 4. It also shows the unit standards which had to be re-assessed (Reas) and what the comment was with regard to the re-assessment (Reass Comm). The scores for this section are summarized in Table 5 .
TABLE 4

LEARNERSHIP RESULTS

\begin{tabular}{|c|c|c|c|c|c|c|c|}
\hline $\begin{array}{l}\text { Mo- } \\
\text { dule }\end{array}$ & Name & Result $\mathrm{M}$ & Mark & $\begin{array}{l}\text { Compe- } \\
\text { tent }^{*}\end{array}$ & $\begin{array}{c}\text { Reass } \\
* *\end{array}$ & $\begin{array}{l}\text { Reass } \\
\text { Com } \\
\star \star \star\end{array}$ & Mark \\
\hline 7468 & $\begin{array}{l}\text { Use mathematics to investi- } \\
\text { gate and monitor the financial } \\
\text { aspects of personal, business, } \\
\text { national and international issue }\end{array}$ & $\begin{array}{l}\text { Achieved } 1 \\
\text { es }\end{array}$ & 100 & Yes & No & No & \\
\hline 7468 & $\begin{array}{l}\text { Use mathematics to investi- } \\
\text { gate and monitor the financial } \\
\text { aspects of personal, business, } \\
\text { national and international issue }\end{array}$ & $\begin{array}{l}\text { Formative } \\
\text { es }\end{array}$ & 71 & Yes & No & No & \\
\hline 7468 & $\begin{array}{l}\text { Use mathematics to investi- } \\
\text { gate and monitor the financial } \\
\text { aspects of personal, business, } \\
\text { national and international issue }\end{array}$ & $\begin{array}{l}\text { Summative } \\
\text { es }\end{array}$ & e 76 & Yes & No & No & \\
\hline 8968 & $\begin{array}{l}\text { Accommodate audience and } \\
\text { context needs in oral } \\
\text { communication }\end{array}$ & Achieved & 0 & No & Yes & Yes & 100 \\
\hline 8968 & $\begin{array}{l}\text { Accommodate audience and } \\
\text { context needs in oral } \\
\text { communication }\end{array}$ & Summative & e 85 & Yes & No & No & \\
\hline 8968 & $\begin{array}{l}\text { Accommodate audience and } \\
\text { context needs in oral } \\
\text { communication }\end{array}$ & Formative & 64 & Yes & No & No & \\
\hline 8969 & $\begin{array}{l}\text { Interpret and use information } \\
\text { from texts }\end{array}$ & Achieved & 0 & No & Yes & Yes & 100 \\
\hline 8969 & $\begin{array}{l}\text { Interpret and use information } \\
\text { from texts }\end{array}$ & Summative & e 85 & Yes & No & No & \\
\hline 8969 & $\begin{array}{l}\text { Interpret and use information } \\
\text { from texts }\end{array}$ & Formative & 64 & Yes & No & No & \\
\hline 8970 & $\begin{array}{l}\text { Write texts for a range of } \\
\text { communicative contexts }\end{array}$ & Summative & e 95 & Yes & No & No & \\
\hline 8970 & $\begin{array}{l}\text { Write texts for a range of } \\
\text { communicative contexts }\end{array}$ & Formative & 64 & Yes & No & No & \\
\hline 8970 & $\begin{array}{l}\text { Write texts for a range of } \\
\text { communicative contexts }\end{array}$ & Achieved & 0 & No & Yes & Yes & 100 \\
\hline 8973 & $\begin{array}{l}\text { Use language and communi- } \\
\text { cation in occupational } \\
\text { learning programmes }\end{array}$ & Achieved & 0 & No & Yes & Yes & 100 \\
\hline 8973 & $\begin{array}{l}\text { Use language and communi- } \\
\text { cation in occupational } \\
\text { learning programmes }\end{array}$ & Formative & 64 & Yes & No & No & \\
\hline 8973 & $\begin{array}{l}\text { Use language and communi- } \\
\text { cation in occupational } \\
\text { learning programmes }\end{array}$ & Summative & e 85 & Yes & No & No & \\
\hline 9015 & $\begin{array}{l}\text { Apply knowledge of statistics } \\
\text { and probability to critically } \\
\text { interrogate and effectively } \\
\text { communicate findings on } \\
\text { life related problems }\end{array}$ & Achieved & 100 & Yes & No & No & \\
\hline 9015 & $\begin{array}{l}\text { Apply knowledge of statistics } \\
\text { and probability to critically } \\
\text { interrogate and effectively } \\
\text { communicate findings on life } \\
\text { related problems }\end{array}$ & Formative & 71 & Yes & No & No & \\
\hline 9015 & $\begin{array}{l}\text { Apply knowledge of statistics } \\
\text { and probability to critically } \\
\text { interrogate and effectively } \\
\text { communicate findings on life } \\
\text { related problems }\end{array}$ & Summative & e 76 & Yes & No & No & \\
\hline
\end{tabular}

KEY: * ${ }^{*}$ Competent (is the learner competent for this module also known as unit standard)

** $=$ Reassess learner (If the learner was not declared competent, then he/she has the opportunity to be reassessed)

$* * *=$ Reassess Comment (Alerts the reader to look for any comment with regard to the pass mark) 
Table 5 gives a summary of each learner's results as shown in Table 4. The results are split into gender and their respective averages as well as a summary of the number of unit standards of the New Venture Creation Learnership that had to be re-assessed if the respondent was not considered competent (refer Table 4). It also shows that on average, each learner (for both the female and the male gender groups) had seven unit standards that had to be reassessed. Respondent 15 of the females seem to have had some problems while respondent 3 of the males proved equally problematic.

\section{TABLE 5}

\section{SUMMARY LEARNERSHIP RESULTS}

\begin{tabular}{|c|c|c|c|c|c|c|c|}
\hline Respondent & Gender & $\begin{array}{c}\text { Ave } \\
\%\end{array}$ & $\begin{array}{c}\text { Total } \\
\text { Number } \\
\text { Reass. }\end{array}$ & $\begin{array}{l}\text { Respon- } \\
\text { dent }\end{array}$ & Gender & Ave \% & $\begin{array}{c}\text { Total } \\
\text { Number } \\
\text { Reass. }\end{array}$ \\
\hline 1 & $\mathrm{~F}$ & 56,53 & 7 & 2 & M & 89,03 & 0 \\
\hline 7 & $\mathrm{~F}$ & 70,98 & 7 & 3 & M & 68,35 & 14 \\
\hline 8 & $\mathrm{~F}$ & 72,44 & 6 & 4 & M & 76,63 & 6 \\
\hline 9 & $\mathrm{~F}$ & 65,55 & 9 & 5 & M & 65,04 & 9 \\
\hline 10 & $\mathrm{~F}$ & 85,93 & 6 & 6 & M & 48,78 & 6 \\
\hline 11 & $\mathrm{~F}$ & 68,02 & 6 & 14 & M & 70,97 & 7 \\
\hline 12 & $\mathrm{~F}$ & 77,48 & 1 & 16 & M & 77,9 & 8 \\
\hline 13 & $\mathrm{~F}$ & 48,34 & 5 & 18 & M & 59,58 & 5 \\
\hline 15 & $\mathrm{~F}$ & 68,83 & 12 & 19 & M & 70,95 & 6 \\
\hline 17 & $\mathrm{~F}$ & 59,56 & 6 & & & & \\
\hline 20 & $\mathrm{~F}$ & 43,22 & 2 & & & & \\
\hline Total & & & 67 & otal & & & 61 \\
\hline Average & & & 7 & Average & & & 7 \\
\hline
\end{tabular}

The data for the FIAT was obtained through two web-based questionnaires (for entrepreneur and leadership qualities), calculated electronically and analyzed individually (Table 6)

\section{DISCUSSION}

The data for Phase I showed that most of the respondents scored above the average for the group (Table 1) while Phase II revealed that $47 \%$ of the respondents (highlighted) scored above the average of 19 for the group (Table 2). The learner is expected to cope at National Qualification Framework (NQF) Level 4 (grade 12 or matric level) where the training material for the New Venture Creation Learnership is pitched. Therefore the Adult Basic Education Level 4 (or ABET Level 4) that is equal to an NQF Level 1 (or Grade 9) at which the learners were evaluated by the Seta, is too low.

The results of the pre-assessment data (Phase II) in Table 3 shows that $58 \%$ of respondents were declared incompetent in terms of simple problem solving and $26 \%$ of respondents in terms of numeracy (mathematical literacy). The results for the New Venture Creation Learnership progress of learners, showed the unit standards completed up to a point and an analysis of these results show that respondents 6,13 and 20 scored below 50\% (Table 5). As a result, no conclusive results were possible other than a telephone interview with the training provider who indicated that all the respondents for this research will most likely complete their learnership.

The results for the Functional Intelligence Assessment (Table 6) show that only $16 \%$ of respondents are likely to become entrepreneurs (respondent 4,5 and 16) of which $5 \%$ are specifically suited to the environment of arts (respondent 4). Of the $16 \%$ potential entrepreneurs there are $11 \%$ (respondents 4 and 16) who also have leadership qualities. The analysis of one respondent was such that no accurate analysis in terms of leadership qualities could be obtained (respondent 5).

TABLE 6

SUMMARY RESULTS: FUNCTIONAL INTELLIGENCE ASSESSMENT TOOL

\begin{tabular}{|c|c|c|c|c|c|c|c|}
\hline $\begin{array}{l}\text { Respon- } \\
\text { dent }\end{array}$ & Gender & Entrep & Leader & $\begin{array}{l}\text { Re- } \\
\text { assessed }\end{array}$ & $\begin{array}{l}\text { In- } \\
\text { consistency }\end{array}$ & $\begin{array}{l}\text { Functional } \\
\text { Tendency }\end{array}$ & Comment \\
\hline 1 & $\mathrm{~F}$ & NO & NO & YES & YES & EXTROVERT & $\begin{array}{l}\text { High risk respondent; dishonest tendencies; information not trusted; } \\
\text { Cannot scientifically verify personality }\end{array}$ \\
\hline 2 & M & NO & NO & NO & Not significant & $\mathrm{N} / \mathrm{A}$ & Respondent is honest but no staying power when the money is absent \\
\hline 3 & & NO & NO & NO & YES & INTROVERT & Not intentional manipulation but is in denial \\
\hline 4 & M & YES (Arts) & YES & NO & Not significant & EXTROVERT & Dishonest; using some impression management; can be a suspect \\
\hline 5 & M & YES & $\mathrm{O}^{*}$ & NO & YES & EXTROVERT & Intentionally using impression management \\
\hline 6 & M & NO & NO & NO & Not significant & INTROVERT & Main problem is with supervisor, Needs to change, \\
\hline 7 & $\mathrm{~F}$ & NO & NO & NO & Not significant & $\mathrm{N} / \mathrm{A}$ & Not trustworthy; using impression management \\
\hline 8 & M & NO & NO & YES & YES & EXTROVERT & Using impression management; problem with supervisor \\
\hline 9 & $\mathrm{~F}$ & NO & NO & NO & Not significant & EXTROVERT & $\begin{array}{l}\text { Needs to investigate her emotional functioning; professional intervention } \\
\text { highly recommended }\end{array}$ \\
\hline 10 & $\mathrm{~F}$ & NO & NO & NO & Not significant & INTROVERT & Should be an artist; in denial or unrealistic; high risk respondent \\
\hline 11 & $\mathrm{~F}$ & NO & NO & NO & YES & $\mathrm{N} / \mathrm{A}$ & Emotional functioning to be attended to; using impression management \\
\hline 12 & $\mathrm{~F}$ & NO & NO & NO & YES & EXTROVERT & Using impression management; untrustworthy \\
\hline 13 & $\mathrm{~F}$ & NO & NO & YES & YES & $\mathrm{N} / \mathrm{A}$ & $\begin{array}{l}\text { Dishonest; problems should be sorted out, Professional intervention } \\
\text { highly recommended }\end{array}$ \\
\hline 14 & M & NO & NO & NO & YES & INTROVERT & Use of manipulation \\
\hline 15 & $\mathrm{~F}$ & NO & NO & NO & YES & EXTROVERT & High risk respondent; indication of the use of manipulation \\
\hline 16 & M & YES & YES & NO & SOME & EXTROVERT & Seems to be functioning optimally; no manipulation suspected \\
\hline 17 & $\mathrm{~F}$ & NO & NO & NO & YES & INTROVERT & Manipulation; impression management \\
\hline 18 & $\mathrm{~F}$ & NO & NO & NO & YES & $\mathrm{N} / \mathrm{A}$ & Use of manipulation; dishonest; ineffective data \\
\hline 19 & M & NO & NO & YES & YES & INTROVERT & Not using manipulation intentionally \\
\hline
\end{tabular}


In terms of functional tendency, Hudson (et al., 2000, p. 16) defines introverts as individuals who "...enjoy things by themselves and become grouchy if around people too long. They have a strong sense of personal space and might find it difficult to share what they are feeling". Extroverts on the other hand are "...rather gregarious and outgoing and enjoy being around people. They become energized by a group rather than overwhelmed. They talk a lot and easily initiate conversations with other people." (Hudson, et al, p.16). The results in Table 6 show that $42 \%$ of respondents showed extrovert tendencies, 32\% showed introvert tendencies while $26 \%$ of respondents rendered results that did not give a clear indication of the individual's functionality.

Summary comments in Table 6 were gleaned from each individual assessment and along with the detailed assessments were confirmed with the author of the FIAT (Whitehouse) and show that:

1. $47 \%$ of respondents $(5,7,8,11,12,14,15,17$ and 18) intentionally tried to manipulate their results but were identified through their inconsistent results, while $11 \%$ manipulated results unintentionally (respondents 3 and 19).

2. $26 \%$ of respondents $(5,7,8,11$ and 12$)$ tried to disguise their results by giving extreme scores thereby hoping to impress with their choice of answers (impression management) while $11 \%$ were in denial about their situation, having scored unrealistic results (respondents 3, $10)$.

3. $11 \%$ of respondents ( 9 and 13 ) had serious problems with their emotional functioning to the extent that it is believed that they should consult a professional person (professional intervention).

- Respondent 9's Lack of Self-worth is definitely understated in reality. The main concern is the fact that her high Dependency level (close to the clinical cut-off point) indicates that the individual seems to have an inability to cope with reality and would therefore resort to external factors such as alcohol, drugs, yoga or meditation for example. People escape reality by using different methodologies to escape from that truth or reality.

- Respondent 13's Inner Insecurity is slightly overactivated and Lack of Self-worth seems to be optimal. However, the reality is that the Inner Insecurity and
Lack of Self-worth have to also be highly-overactivated. This is due to the fact that both her Frustration and Stress levels are highly over-activated especially her Helplessness IIS which is close to the clinical cut-off point, at which stage irrationality comes into play. The result of this scenario would be depression and withdrawal.

4. $63 \%$ of respondents $(1,3,5,8,11,12,13,14,15,17$ 18 and 19) revealed definite inconsistent results while $5 \%$ (respondent 16) showed some inconsistency and the $32 \%$ remainder of respondents $(2,4,7,8,9$ and 10) show some or an insignificant degree of inconsistency in their results. Only $15 \%$ of respondents (1, 8 and 13) should be re-assessed due to the extent of their inconsistency.

The success of achieving the primary research goal can further be interpreted as being able to identify various aspects of the respondents results shown in Table 6 that are valuable for future research:

1. Highlighting inconsistent results - all the respondents' ratings were inconsistent to some extent or the other, but viable enough to allow a conclusion. Identifying inconsistencies in the responses of the respondents either validated certain statements resulting from the interpretation of the assessments or motivated why one could not come to a conclusion about an aspect, for example, respondent 1 shows signs of Paranoia (fear, suspicion, mistrust, people talking behind your back) which is not consistent with her level of Inner Insecurity (not in a state of feeling secure); If a person has a feeling of insecurity, it is likely that they would also have a Lack of Self-worth. The candidate's Paranoia score is a sure indication that the candidate has a higher level of Inner Insecurity in reality.

2. Exposing manipulative behaviour of respondents in trying to conceal their true feelings.

3. Identifying respondents who need the intervention of a professional person as these respondents show suicidal tendencies or some form of suppressed anger which could erupt unannounced.

4. Identifying various personality traits (e.g. dishonesty) that are warning signs for existing and potential employers.

5. Identifying potential entrepreneurs.

\section{SETA}

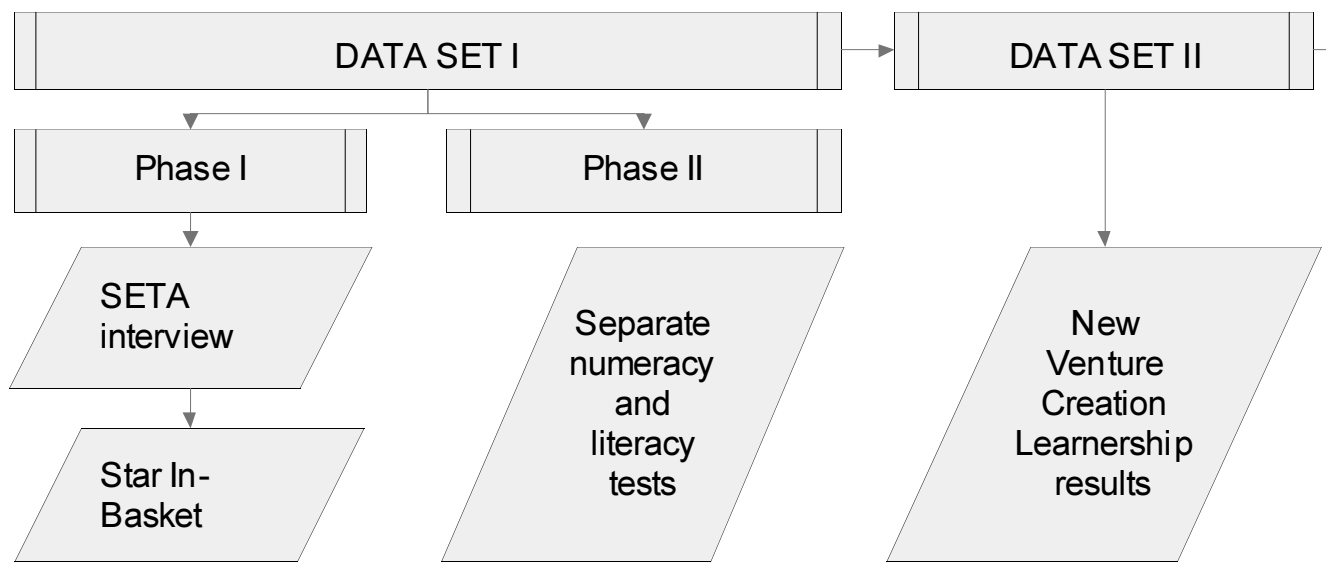

Figure 2: Research approach
Scientific Measuring Instrument

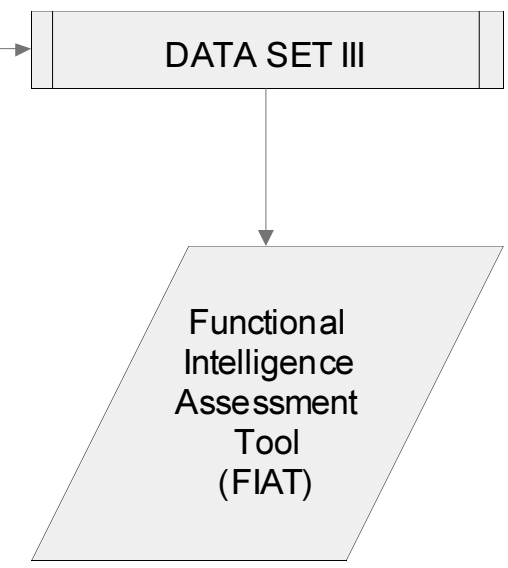


6. Identifying leadership qualities.

7. Identifying respondents who need to be confronted about their ratings to repeat the assessment.

8. Highlighting respondents who did in fact reveal their true feelings and were therefore honest in their assessment.

The holistic approach to assessing the functionality of an individual gives the person a vast number of areas known as super constructs (self perception and emotional functioning; relationships and corporate functioning, personal and organizational value comparison) that will either highlight a serious situation or spell out how the individual will react and interact in certain situations.

\section{REFERENCES}

Anonymous (n.d.) a. Definition of perception. Available from http://www.thefreedictionary.com/perception. (Accessed 10 September 2005).

Anonymous, (n.d.) b. Meyers Briggs Type Indicator. Available from http://www.myersbriggs.org/my\%5Fmbti\%5F personality\%5Ftype/mbti\%5Fbasics/. (Accessed 8 July 2005; 29 March 2006).

Anonymous (n.d.). The Bar-On Model of Emotional-Social Intelligence (ESI). (n.d.). Available from http://www. opsltd.com/www/content/content/default.asp?pid=139. (Accessed 23 April 2005).

Anonymous (n.d.). The Bar-On Model of Emotional-Social Intelligence (ESI). (n.d.). Available from http://www. eiconsortium.org/research/baron_model_of_emotional_soci al_intelligence.htm. (Accessed 5 May 2005).

Anonymous (1995) m. Department of Trade and Industry. White Paper On National Strategy For The Development And Promotion Of Small Business In South Africa. Notice 213 Of 1995. Available from http://www.polity.org.za/html/ govdocs/white_papers/smallbiz.html? rebookmark=1 (Accessed 9 February 2005).

Anonymous (2004) p. Regulatory Inflation. The Role of the Commission and Regulatory Impact Assessment. Available from http://www.compcom.co.za/resources/newsletter\%20\%20oct\%2004/html/pages/5\%20Regulatory.html. (Accessed 9 February 2005).

Anonymous (1999) q. Developing the Small Business Sector in South Africa - A review of regulatory and other obstacles by the South African Chamber of business. Available from http://www.sacob.co.za/SmallBusiness/Smb.pdf. (Accessed 9 February 2005).

Bar-On, R. (1997a). The Emotional Quotient Inventory (EQ-i): A test of emotional intelligence. Toronto, Canada: Multi-Health Systems, Inc.

Bar-On, R. (1997b). The Emotional Quotient Inventory (EQ-i): Technical manual. Toronto, Canada: Multi-Health Systems, Inc.

Bar-On, R., and Handley, R. (2003a). The Bar -On EQ-360. Toronto, Canada: Multi-Health Systems.

Bar-On, R., and Handley, R. (2003b). The Bar -On EQ-360: Technical manual. Toronto, Canada: Multi-Health Systems.

Botha, JH., Calder, J., Fichardt, GA., Bosman, AJ., Slabbert, J., Smuts, M., Van den Berg, LJ and Windsor, WH (1951). Kommissie van Ondersoek in Sake Nywerheidswetgewing: 163 par 1122 \& 1123.

Byers, T., Kist, H and Sutton, R.I. (1997). Characteristics of the entrepreneur: Social creatures, not sole heros. Prepared for the Handbook of Technology Management. Ed. R.C. Dorf. Boca
Raton, Florida. CRC Press. Available from http:// www.stanford.edu/class/e145/materials/Characteristics.html. Accessed 15 September 2004.

Carland, J.W., Jr., Carland, J.A., and Hoy, F. (1992). The entrepreneurship index: A theoretical and empirical validation. Frontiers of Entrepreneurship Research. Wellesley, MA.

Charney, A.H. and Liebcap, G.D. (2002). The contribution of entrepreneurship education: An analysis of the Berger programme. International Journal of Entrepreneurship Education (3): 1-34.

Carree, M.A. and Thurik, A.R. (2002:4). The Impact of Entrepreneurship On Economic Growth. Available from http://www.wiwi.tu-freiberg.de/wipol/pdffiles/ seminar2003/CareeThurik2002.pdf. (Accessed 16 January 2005).

Department of Labour (2001a). Human Resource Development Strategy for South Africa - A Nation at Work for a Better Life for All: 11 Available from http://education.pwv.gov.za/Policies\% 20and\%20Reports/2001_Report/Dedu-duncan-Pg37.pdf. (Accessed 12 August 2004).

Department of Labour (2001b). National Skills Development Strategy - Setting the Context: $2^{\text {nd }}$ edition: 6,7,8.

Dubrin, A. J., Ireland, R.D. and Williams, J.C. (1989). Management and Origination. Ohio. South-Western Publishing Company. Cincinnati.

$\mathrm{Du}$ Pre, R (2004). Coping with changes in Higher Education in South Africa. Available from http://face.stir.ac.uk/Paper101RoyduPre_000.htm. (Accessed 2 June 2004).

Faris, S.H. (1999). Seeking entrepreneurial origins: Are entrepreneurs born or made. Kauffman Center for Entrepreneurial Leadership, Digest 99:1.

Fryer, D (2003). Coordination Failure and Employment in South Africa. Available from http://www.tips.org.za/research/ papers/pdfs/690.pdf. Accessed 4 October 2004.

Hashemi, K and Shirazi, M (1994). Motivational elements of Iran industry managers in choosing growth strategies. Shiraz University.

Hernandez-Gantes, V.M., Sorensen, R.P., Nieri, A.H. (n.d.). Fostering Entrepreneurship Through Business Incubation: The Role And Prospects of Postsecondary Vocational-Technical Education (Report 1: Survey Of Business Incubator Clients And Managers) (Mds-893). Available from http://Ncrve. Berkeley.Edu/Summaries/893sum.Html. (Accessed 15 August 2004).

Horne, B.I. (1999). An assessment package for a life counseling model. Doctoral dissertation. Rand Afrikaans University: 221,225

Hudson, W.W., Faul, A.C. and Hanekom, B 2000. Corporate Behavioral Screening Inventory. First edition. Copyright 2000 - Perspective Training College: 15, 16.

Hynes, B (1996). Entrepreneurship education and training: Introducing entrepreneurship into non-business disciplines. Journal of European Industrial Training, 20 (8): 10 - 17.

Miner, J.B. (1994). Role motivation theories. U.S.A: Routledge: 62-68.

Neuman, W.1. (2003). Social Research Methods - Qualitative and Quantitative Approaches: 16, 145.

Van Reenen, R.J., Visser, M., Arndt, E.H.D., Champion, H.F., Davidson, D.M., Downes, A.J., Freestone, W (1935). Report on the Industrial Legislation Commission: 142, 147-149,156.

Schwenke, J and Van Heerden, L 2002. Entrepreneurship the Answer to Job Creation. Available from http://www. businesspartners.co.za/Media/releases/jobcreation.pdf. (Accessed 7 July 2004).

Whitehouse, N (2002). Functional Intelligence. Available form http://functionalintelligence.com. (Accessed 2,15,17,18,22, 24,26,30 August 2005). 